\title{
Obsessive-Compulsive-Bipolar Disorder Comorbidity: A Case Report
}

\section{Comorbilidade Obsessivo-Compulsiva-Bipolar: Um Caso Clínico}

João Pedro Ribeiro* ${ }^{*}$, João Coelho Silva*

\section{ABSTRACT:}

Anxiety disorders have been described as features of Bipolar Disorder (BD), and Obsessive-compulsive-bipolar disorder (OCBD) may occur in as many as $56 \%$ of obsessive-compulsive patients. Mania in Obsessive-Compulsive Disorder (OCD) can occur either as an independent comorbidity or as a result of an antidepressant-induced switch. We report the case of a 38-year-old male with a 3 year diagnosis of OCD treated with antidepressants, admitted due to a manic episode, and describe diagnostic and treatment challenges of this comorbidity.

Key-Words: Affective Disorder; Anxiety Disorder; Mania; Manic Episode.

\section{RESUMO:}

As Perturbações da Ansiedade têm sido descritas como manifestações da Perturbação Bipolar, e a comorbilidade Obsessivo-Compulsiva-Bipolar pode ocorrer em até $56 \%$ dos pacientes diagnosticados com uma Perturbação Obessivo-Compulsiva (POC). A mania na POC pode ocorrer como uma comorbilidade independente ou como resultado de terapêutica antidepressiva.
No presente trabalho, descreve-se o caso de um homem de 38 anos diagnosticado com uma POC desde há 3 anos, medicado com antidepressivos, admitido por um episódio maníaco, e os desafios diagnósticos e terapêuticos desta comorbilidade.

Palavras-Chave: Perturbação Afectiva; Perturbação de Ansiedade; Mania; Episódio Maníaco.

\section{INTRODUCTION}

Anxiety disorders have been historically described as features of Bipolar Disorder (BD) and Obsessive-compulsive-bipolar disorder (OCBD) comorbidity has been referred in literature ${ }^{1}$.

A survey reports that $55,8 \%$ of patients with diagnosed Obsessive-Compulsive Disorder (OCD) may develop BD in their lifetime ${ }^{2}$, while others estimate its prevalence ranging from $10 \%$ to $20 \%$. Many studies report an episodic course as a characteristic feature of OCD comorbid with $\mathrm{BD}^{1-4}$.

Bipolar comorbidity in OCD is a relevant phenomenon and has clinically significant influence on its symptomatological expression and complications ${ }^{5}$. Patients with this comorbidity

\footnotetext{
* Psychiatry and Mental Health Department, Centro Hospitalar Tâmega e Sousa, EPE, $₫$ joaoribeiro@live.com

Recebido / Received: 27/06/2013 - Aceite / Accepted: 21/07/2013
} 
present early in life compared with pure $0 \mathrm{CD}^{6}$ and their psychopathology involves existential, philosophical, hoarding, sexual obsessions and odd superstitions $s^{4,6-8}$.

OCBD comorbidity has relevant treatment outcome implications, since bipolarity has a negative influence on therapeutic compliance and response ${ }^{5}$. OCD is known to worsen in depression and improve in hypomania/mania $^{2,4}$. Mania in OCD can occur either as an independent comorbidity or as a result of an antidepressant-induced switch in a patient on anti-OCD drugs ${ }^{9,10}$.

We describe and discuss some aspects of this psychiatric comorbidity, with emphasis on its diagnostics and management, based on a case report.

\section{CASE REPORT}

$\mathrm{Mr} \mathrm{J}$. is a 38-year-old male who lives with his family, has a stable working situation at a shoe factory and was apparently healthy, although he showed traits of an obsessive personality in his adolescence with few related compulsive behaviours. He had been admitted at a psychiatric ward for a probable depressive episode 3 years before, and has since then been followed in our outpatient psychiatric consultation. He was prescribed antidepressants and had a history of irregular improvement in his obsessive thoughts. Notably, his mother had a history of depressive episodes and 3 siblings were diagnosed with OCD.

His relatives brought him to hospital after an episode of uncontrollable behaviour. Two weeks prior to admission he began showing signs of gradual elevated mood, talkativeness, restlessness, agitation, hyperactivity and decreased need for sleep. He was admitted to our ward presenting psychotic symptoms of grandeur delusion, disorganized speech and flight of ideas. He would start bragging about his capability of speaking several languages, his amazing memory skills, describing himself as a future warrior (while sketching it on paper), and claiming to be in the process of writing a book in the near future. He mentioned his special relationship with the opposite sex, whose intent was to seduce him, illustrated with descriptions of suspicious behaviour from other patients at the ward. When prompted for the reasons for such happenings, his explanations were vague and philosophically rooted.

A screening of substances of abuse and an assessment of general medical conditions (such as thyroid function) showed negative results. The described manic symptoms had treatment priority, thus he was prescribed an antipsychotic - olanzapine $20 \mathrm{mg}$ daily - that produced a mild effect in his disorganized thought content, but caused a strong daily somnolence. The dosage was adjusted and a mood stabilizer - valproic acid (up to 1000mg daily) - was added. As a result, his manic symptoms improved; however, his worries and obsessions became more organized and prominent.

After 2 weeks of slow behavioural improvement, he showed signs of intrusive ego-dystonic thoughts revolving about his existential being, his sexual performance and his personal past and present relationships. His emotional lability was especially noticeable during the clinical interviews when prompted about the subjects regarding his affective history. One week later, the obsessive symptoms gained 
preponderance and we initiated a slow titration of sertraline (50mg daily). His judgment for the morbid state was slowly recovered, accompanied by the diminishing impact of his obsessive intrusive thoughts. Behavioural adequacy was obtained and functioning restored to a point of clinical safety for the patient's return to his home and family, work and daily life. Obsessive thoughts were still prominent during his follow-up consultation. A minimal dose of antipsychotic (olanzapine 10mg daily) was maintained for only 4 months post-admission along with the SSRI (sertraline $75 \mathrm{mg}$ daily) and the referred dose of the mood stabilizer, both still prescribed at the last consultation. Clinically there have been no remarkable modifications.

\section{DISCUSSION}

This case report illustrates the management of an inaugural manic episode in a patient with a previous diagnosis of $\mathrm{OCD}$.

As a complex comorbidity, OCBD represents a diagnostic and therapeutic challenge implying further systematic exploration. It has been referred that OCBD symptomatological expression may herald an episodic course of OCD with higher rates of certain obsessions (aggressive/impulsive, sexual, religious and obsessional doubts) ${ }^{2,4}$. Cases have been reported in which OCD symptoms remitted during mania and reappeared with its remission 5 .

As described in this clinical case, bipolar symptoms prompted the admission and were responsible for the first pharmacological interventions. Scientific evidence favours this preference $^{11}$. The later onset of OCD symptoms prompts a different therapeutic intervention thus elevating the risk for relapsing hospitalizations and complex pharmacological interventions ${ }^{4}$. As there is no well-established treatment of OCBD, this case report and its pharmacological management may prompt further clinical trials for a possible standard treatment assessment.

\section{Conflicting Interests / Conflitos de Interesse:}

The authors have declared no competing interests exist.

Os autores declaram não ter nenbum conflito de interesses relativamente ao presente artigo.

\section{Funding / Fontes de Financiamento:}

The authors have declared no external funding was received for this study.

Não existiram fontes externas de financiamento para a realização deste artigo.

\section{References / Bibliografia}

1. Mcintyre RS, Soczynska JK, Bottas A, Bordbar K, Konarski JZ, Kennedy SH: Anxiety Disorders And Bipolar Disorder: A Review. Bipolar Disord. 2006; 8(6): 665-676.

2. Perugi G, Akiskal HS, Pfanner C, et al: The Clinical Impact of Bipolar And Unipolar Affective Comorbidity on obsessive-compulsive Disorder. Journal of affective disorders. 1997; 46(1):15-23.

3. Chen YW, Dilsaver, SC: Comorbidity for obsessive-compulsive disorder in bipolar and unipolar disorders. Psychiatry Research. 1995; 59(1-2):57-64.

4. Mahasuar R, Janardhan Reddy YC, Math SB: Obsessive-compulsive disorder with and with- 
out bipolar disorder. Psychiatry and clinical neurosciences. 2011; 65(5): 423-33.

5. Pallanti S, Grassi G, Sarrecchia ED, Cantisani A, Pellegrini M: Obsessive-compulsive disorder comorbidity: Clinical assessment and therapeutic implications. Frontiers in Psychiatry. 2011; 2: 70.

6. Masi G, Perugi G, Toni C, Millepiedi S, Mucci $\mathrm{M}$, Bertini N, et al: Obsessive compulsive bipolar comorbidity: focus on children and adolescents. Journal of affective disorders. 2004; 78(3):175-183.

7. Joshi G, Wozniak J, Petty C, Vivas F, Yorks D, Biederman J, et al: Clinical characteristics of comorbid obsessive-compulsive disorder and bipolar disorder in children and adolescents. Bipolar Disorders. 2010; 12(2):185-195.
8. Koyuncu A, Tükel R, Özyıldırım Í, Meteris H, Yazicib 0: Impact of obsessive- compulsive disorder comorbidity on the sociodemographic and clinical features of patients with bipolar disorder. Comprehensive Psychiatry. 2010; 51(3):293-297.

9. Annigeri B, Raman R, Appaji R: Obsessive compulsive disorder with bipolar mood disorder: A rare comorbidity in India. Indian journal of psychological medicine. 2011; 33(1): 83-85.

10. Philip J, Janaki R: Antidepressant-induced mania in obsessive compulsive disorder. Indian Journal of Psychiatry. 2012; 54(2):194-195.

11. Raja M, Azzoni A: Clinical management of obsessive-compulsive-bipolar comorbidity: a case series. Bipolar Disorders. 2004; 6(3):264-270. 